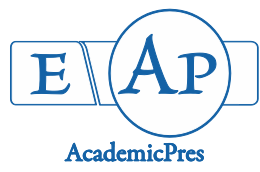

Mohammad AO et al. (2020)

Notulae Scientia Biologicae 12(2):258-263

DOI: $10.15835 / \mathrm{nsb} 12210628$

Research Article

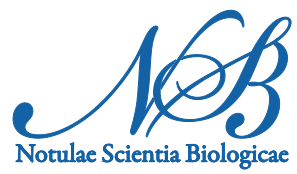

\title{
Evaluation of API 20E system in fluorescent Pseudomonas identification from button mushroom Agaricus bisporus cultivation casing soil
}

\author{
Anwar O. MOHAMMAD ${ }^{1 *}$, Abdulkareem E.S. ALKURTANY², \\ Abdullah A. HASSAN ${ }^{3}$ \\ ${ }^{1}$ University of Sulaimani, Natural Resources Department, College of Agricultural Engineering Sciences, \\ Al-Sulaymaniyah, Iraq; anwar.mhamad@univsul.edu.iq ( ${ }^{*}$ corresponding author) \\ ${ }^{2}$ Tikrit University, Department of Soil and Water Science, College of Agriculture, Tikrit, Iraq; alkurtany@tu.edu.iq \\ ${ }^{3}$ Tikrit University, Department of Plant Protection, College of Agriculture, Tikrit, Iraq; drabdullah.has67@tu.edu.iq
}

\begin{abstract}
Bacterial activity, mainly Pseudomonas spp. plays a vital role in the fruiting process of white button mushroom, hence a rapid procedure to identify these bacteria is crucial. In the current study, the validity of commercial identification system, Analytical profile index API 20E to identify Pseudomonas isolates from mushroom casing soil were assessed. Using API strips fifty bacterial isolates from a selective medium (King B medium) were examined, all isolates were belonged to the genus Pseudomonas according to API 20E identification systems. However, only $74 \%$ of Pseudomonas bacteria were identified to species level. The molecular identification using $16 \mathrm{~S}$ rRNA gene was used as a reference tool to identify bacteria at the species level. The results show that the accuracy of the system to classify florescent Pseudomonas to species level was $60 \%$. This was species dependant, and the system accuracy were $100 \%, 87.5 \%, 81.3 \%$ and $63 \%$ in identifying $P$. aeruginosa, $P$. putida, $P$. fluorescens and $P$. tolaasii respectively. Our finding indicates that although the classification of the Pseudomonas genus with API 20E system is useful, but it is not enough to distinguish these bacteria to species level, genomic studies are necessary to confirm the exact taxonomic position of $P$ seudomonas spp.
\end{abstract}

Keywords: bacteria; biochemical tests; classification; fluorescent Pseudomonas; PCR

\section{Introduction}

The fungus white button mushroom (Agaricus bisporus) is world's most cultivated mushroom species. The formation of mushroom fruit body requires the application of $3-5 \mathrm{~cm}$ casing layer which is made from material such as peat, soil, and granulated bark to mycelium colonized compost (Long and Jacobs, 1974). The casing layer supports beneficial microbial populations that release growth stimulants, which are reportedly involved in stimulating the initiation of mushroom. Fluorescent Pseudomonas represents up to $50 \%$ of the 
bacterial population of the casing layer, of which the Pseudomonas putida is the most crucial (Noble et al., 2003). However, not all Pseudomonas bacteria are beneficial in casing layer, for instance, few species had been isolated with the pathogenic ability to cause mushroom disease (Godfrey et al., 2001, Munsch et al., 2002). This includes the brown blotch disease that is caused by two pathogenic bacterium $P$. tolaasii and P. reactans (Gill, 1995).

Rapid identification of Pseudomonas bacteria in casing soil is a big challenge for the mushroom producers, for their impact on mushroom yield and quality (Mohammad and Sabaa, 2015; Kosanovic, et al., 2019). The API 20E which detects 20 biochemical reactions, is a traditional method for the identification of Enterobacteriaceae, it is accepted as a rapid system for the identification of enteric and non-fermentative bacteria in many clinical bacteriological laboratories, and often is used to replace conventional biochemical tests method (O'Hara et al., 1992; O'Hara, 2005). However, few studies have been reported evaluating this rapid identification system to investigate bacterial isolate from the soil. This study aimed to evaluate the performance of API 20E for the identification of fluorescent Pseudomonas from mushroom casing soil, taking the identification by the molecular method as the gold standard.

\section{Materials and Methods}

\section{Sampling protocols}

A sample of spent casing soil was collected from the mushrooms project (University of Tikrit/ College of Agriculture), and (10 gm) of spent casing soil was suspended in $90 \mathrm{ml}$ sterilized normal saline $(0.85 \% \mathrm{NaCl})$ and shaken vigorously at $150 \mathrm{rpm}$ at room temperature for one h. The resulting slurry was serially diluted, appropriate dilutions $\left(10^{-4}\right)$ were made in normal saline, and $0.1 \mathrm{ml}$ of this suspension was spread plated on King's B medium (KB) (King et al., 1954). The plates were incubated at $28{ }^{\circ} \mathrm{C}$ for $48 \mathrm{~h}$. Single colonies producing green/yellow fluorescent pigments streaked on KB plates. Single colonies producing green/yellow fluorescent pigments streaked on KB plates. Gram-staining was performed by following the Burke method (Beveridge et al., 2007). The oxidase reaction was tested using oxidase reagent $1 \%(\mathrm{w} / \mathrm{v}$ ) tetra-methyl-pphenylenediamine dihydrochloride. Catalase activity was recorded by observation of bubble formation after adding $3 \%(\mathrm{v} / \mathrm{v})$ hydrogen peroxide $\mathrm{H}_{2} \mathrm{O}_{2}$.

\section{Analytical profile index (API 20E) system for bacterial identification}

Fifty $(\mathrm{n}=50)$ Pseudomonas isolates cultured from the casing soil samples were randomly collected. For each isolate, an API 20E strips (bioMérieux, Marcy-I'Etoile, France) were inoculated and incubated according to the manufacturer's instructions. The likelihood of Fluorescent Pseudomonas was calculated, using the manufacturer's coding system based on reactions to reagents in the 20 compartments.

\section{Polymerase Chain Reaction (PCR) identifications confirmation}

A single colony of identified Pseudomonas species by API 20E was taken from the cultured plate and inoculated into $10 \mathrm{ml}$ of $\mathrm{KB}$ broth. The isolated Pseudomonas incubated at $28^{\circ} \mathrm{C}$ for 24 hours. Bacterial cells harvested from three $\mathrm{ml}$ of the bacterial suspension by centrifugation at $4,000 \mathrm{~g}$ for 10 minutes. The DNA was extracted using DNA-Sorb-B extraction kit (Sacace, Biotechnologies., Italy) The extracted DNA stored at -20 ${ }^{\circ} \mathrm{C}$.

All the PCR mixes were performed in $(1.5 \mathrm{ml})$ Eppendorf test tube containing $\approx 50-100 \mathrm{ng}$ of bacterial genomic DNA solution, $5 \mu \mathrm{L}$ of 10x PCR buffer, $200 \mu \mathrm{M}$ of each deoxynucleotide triphosphate (dNTP), 2 $\mathrm{mM}$ of $\mathrm{MgCl}_{2}, 0.5 \mu \mathrm{M}$ of primers and $1 \mathrm{U}$ of Taq polymerase (Amersham-Pharmacia). DNA $16 \mathrm{~S}$ region amplification was perform using the species-specific primer set (Table 1). The following thermal profile was used, 5 min at $94^{\circ} \mathrm{C} ; 35$ cycles consisting of $94^{\circ} \mathrm{C}$ for $1 \mathrm{~min}, 55^{\circ} \mathrm{C}$ for $1 \mathrm{~min}, 72{ }^{\circ} \mathrm{C}$ for $2 \mathrm{~min} ; 35 \mathrm{cycles}$ 
consisting of $92{ }^{\circ} \mathrm{C}$ for $45 \mathrm{~s}, 60{ }^{\circ} \mathrm{C}$ for $45 \mathrm{~s}, 72{ }^{\circ} \mathrm{C}$ for $2 \mathrm{~min}$; final extension of $72{ }^{\circ} \mathrm{C}$ for $2 \mathrm{~min}$. The amplifications performed in DNA thermal cycle (Eppendorf, Germany).

Table 1. Primers used in the study

\begin{tabular}{|c|c|c|}
\hline Primer* $^{*}$ & Sequence & References \\
\hline 16SPSEfluF & $5^{\prime}$ TGCATTCAAAACTGACTG-3' & Scarpellini et al. (2004) \\
\hline 16SPSEfluR & $5^{\prime}$ AATCACACCGTGGTAACCG-3' & Scarpellini et al. (2004) \\
\hline 16SPSEaeF & $5^{\perp} T G C A T C C A A A A C T A C T G A-3^{\prime}$ & This study \\
\hline 16PSEaeR & $5^{\prime} A A T C A C T C C G T G G T A A C C G-3^{\prime}$ & This study \\
\hline 16SPSEtolF & $5^{\perp} T G C A T T C A A A A C T G A C T G-3^{\prime}$ & This study \\
\hline 16SPSEtolR & $5^{\prime} C C C G G G A A C G T A T C A C C G-3^{\prime}$ & This study \\
\hline 16SPSEputF & $5^{\prime} T G C A T C C A A A A C T G G C A A G-3^{\prime}$ & This study \\
\hline 16SPSEputR & $5^{\perp} A A T C A C A C C G T G G T A A C C G-3^{\prime}$ & This study \\
\hline
\end{tabular}

${ }^{*}$ Database of $16 \mathrm{~S}$ rRNA sequence in National Center for Biotechnology Information (NCBI) gave necessary information to design these species-specific primers, using the Basic Local Alignment Search Tool (BLAST).

PCR amplification products were analysed on agarose gel (1.0\%) using a horizontal electrophoresis unit. The gel was immersed in 1 X TAE buffer containing $0.2 \mu \mathrm{g} \mathrm{ml}{ }^{-1}$ ethidium bromide (Scarpellini et al., 2004) and photographed by Bio-Rad gel doc system.

\section{Results}

All the considered bacterial isolates were gram-negative, produced yellow-greenish florescent pigmentation on $\mathrm{KB}$ medium and gave a positive reaction to oxidase and catalase tests.

According to the results from API 20E system, all Bacterial isolates from King's B medium belonged to the genus Pseudomonas (Table 2); however, only $74 \%$ were to species level, and the accuracy of identified bacteria to species level was $60 \%$ when compared to the molecular method.

Table 2. Identification and accuracy results for $P$. putida, $P$. fluorescens, $P$. tolaasii, $P$. aeruginosa by API $20 \mathrm{E}$ ( $n$ is the number of bacteria isolates)

\begin{tabular}{|c|c|c|c|c|c|}
\hline & $\begin{array}{c}\text { P.putida } \\
n=8\end{array}$ & $\begin{array}{c}\text { P. fluorescens } \\
n=16\end{array}$ & $\begin{array}{c}\text { P. tolaasii } \\
n=8\end{array}$ & $\begin{array}{c}\text { P. aeruginosa } \\
n=5\end{array}$ & $\begin{array}{c}\text { Total isolates } \\
n=50\end{array}$ \\
\hline $\begin{array}{c}\text { Total } \\
\text { identification to } \\
\text { species level }\end{array}$ & 8 & 16 & 8 & $57(74 \%)$ \\
\hline $\begin{array}{c}\text { Correct } \\
\text { identification at } \\
\text { the species level }\end{array}$ & $7(87.5 \%)$ & $13(81.3 \%)$ & $5(63 \%)$ & $5(100 \%)$ & $30(60 \%)$ \\
\hline $\begin{array}{c}\text { Inaccurate } \\
\text { identified to } \\
\text { species level }\end{array}$ & $1(12.5 \%)$ & $3(18.7 \%)$ & $3(37 \%)$ & $0(0 \%)$ & $20(40 \%)$ \\
\hline $\begin{array}{c}\text { Identification to } \\
\text { genus level }\end{array}$ & $8(100 \%)$ & $16(100 \%)$ & $8(100 \%)$ & $5(100 \%)$ & $50(100 \%)$ \\
\hline
\end{tabular}

To confirm the identification of Pseudomonas isolates at the molecular level, the $16 \mathrm{~S}$ rRNA gene sequence was amplified to identify Pseudomonas spp. isolated from the casing soil. 
A pair of primer were used for the amplification of $16 \mathrm{~S}$ rRNA genes in $P$. fluorescens; forward primer (16SPSEfluF) and the reverse primer (16SPSEfluR). The PCR result showed that there is a fragment of 848 bp of $16 \mathrm{~S}$ rRNA, which is a specific amplification for $P$. fluorescens species. Scarpellini et al. (2004b) obtained similar results by using the same pair of primers to identify $P$. fluorescens. To identify $P$. tolaasii, a speciesspecific amplification of the $757 \mathrm{bp}$ of $16 \mathrm{~S}$ rRNA fragment obtained using two primers forward primer 16SPSEtolF and reverse primer 16SPSEtolR. Eight isolates identified as P. tolaasii using API 20E system but only five of them confirmed to be accurate using PCR amplification assay. For confirming the identification of tested $P$. aeruginosa and $P$. putida to the species level, based on the alignment of the $16 \mathrm{~S}$ rRNA gene sequence available in GenBank, two primer pairs were used to confirm species identification. PCR products of the 874 bp and 848 bp were obtained in confirmation of $P$. aeruginosa and $P$. putida species identification, respectively.

\section{Discussion}

The API 20E diagnostic is a traditional method for the identification of Enterobacteriaceae (Koneman et al., 1997). In this study, we have examined the suitability of API 20E system in the identification of Pseudomonas bacteria from mushroom casing soil. The results show $40 \%$ of Pseudomonas isolates were not identified to species level. Previous studies about the use of API 20E have reported both good and inaccurate sample classifications (O'Hara et al., 1992; Popovic et al., 2004). Topic Popovic et al., (2004) found that the accuracy API 20E to identify Pseudomonas spp bacteria was $37 \%$. Biochemical testing is frequently required to positively identify these organisms and require the use of multiple assays, with a composite result predicting the most likely identification (Kiska and Gilligan, 2003).

API 20E system identified 37 bacterial samples to species level from these 30 isolates (60\%) confirmed to be correct using gene amplification. Two isolates that according to API $20 \mathrm{E}$ belonged to $P$. fluorescens, we found that they belonged to $P$. putida using the molecular method. Furthermore, we found that $26 \%$ of species were not sufficiently identified to species level. The overall accuracy of the API 20E system to classify florescent Pseudomonas to species level was 60\%. Furthermore, in this study, the accuracy of API 20E system were 100\%, $87.5 \%, 81.3 \%$ and $63 \%$ in identifying $P$. aeruginosa, $P$. putida, $P$. fluorescens and $P$. tolaasii respectively (Table 2).

In a previous study, Drancourt et al. (2000) suggested that Some bacteria are difficult to identify phenotypically using the schemes of identification with commonly used outside reference laboratories. For this reason, the $16 \mathrm{~S}$ rRNA gene sequence offers a useful method for the identification of bacteria because these genes are conservative. The $16 \mathrm{~S}$ rRNA gene sequence had long been used as a taxonomic method in determining the phylogenies of bacterial species. Selective amplification of Pseudomonas 16S rRNA gene sequence and PCR chain reaction was used to reveal and differentiate Pseudomonas species from clinical and environmental samples (Porteous et al., 2002). Clarridge (2004) described that $16 \mathrm{~S}$ ribosomal RNA sequencing could be claimed as the reference method for bacteria species identification in research laboratories. Genotypic identification is emerging as an alternative or complement method to conventional phenotypic identification (Kolbert and Persing, 1999; Franzetti and Scarpellini, 2007). The public databases (GenBank, Nucleotide Sequence Database at the European Molecular Biology Laboratory, DNA Data Bank of Japan, RDP II) contain a significant amount of bacterial $16 \mathrm{~S}$ rRNA sequences that allows rapid analysis and provide phylogenetically meaningful information (Bosshard et al., 2006). The classification of the Pseudomonas genus employing physiological and biochemical characteristics is useful, but it is not enough to distinguish the Pseudomonas species: genomic studies are needed to confirm the exact taxonomic position of Pseudomonas spp. 


\section{Conclusions}

Physiological and biochemical characteristics (API 20E system) could be regarded as a fast identification approach, but it is not enough to distinguish the Pseudomonas species; genomic studies are needed to confirm the exact taxonomic position of Pseudomonas spp.

\section{Acknowledgements}

The authors wish to thank the University of Tikrit - College of Agriculture and the University of Sulaimani-College of Agriculture for all assistance provided.

\section{Conflict of Interests}

The authors declare that there are no conflicts of interest related to this article.

\section{References}

Beveridge TJ, Lawrence JR, Murray RGE (2007). Sampling and staining for light microscopy. Methods for General and Molecular Microbiology 3:19-33. https://doi.org/10.1128/9781555817497.ch2

Bosshard PP, Zbinden R, Abels S, Böddinghaus B, Altwegg M, Böttger EC (2006). 16S rRNA gene sequencing versus the API 20 NE System and the VITEK 2 ID-GNB card for identification of nonfermenting Gram-negative bacteria in the clinical laboratory. Journal of Clinical Microbiology 44:1359-1366. https://doi.org/10.1128/JCM.44.4.1359-1366.2006

Clarridge JE (2004). Impact of $16 \mathrm{~S}$ rRNA gene sequence analysis for identification of bacteria on clinical microbiology and infectious diseases. Clinical Microbiology Reviews 17:840-862.

Drancourt M, Bollet C, Carlioz A, Martelin R, Gayral JP, Raoult D (2000). 16S Ribosomal DNA sequence analysis of a large collection of environmental and clinical unidentifiable bacterial isolates. Journal of Clinical Microbiology 38:3623-3630.

Franzetti L, Scarpellini M (2007). Characterisation of Pseudomonas spp. isolated from foods. Annals of Microbiology 57:39-47. https://doi.org/10.1007/BF03175048

Gill WM (1995). Bacterial diseases of Agaricus mushrooms. Reports of the Tottori Mycological Institute (Japan).

Godfrey SAC, Harrow SA, Marshall JW, Klena JD (2001). Characterization by 16S rRNA sequence analysis of pseudomonads causing blotch disease of cultivated Agaricus bisporus. Applied and Environmental Microbiology 67:4316-4323.https://doi.org/10.1128/AEM.67.9.4316-4323.2001

King EO, Ward MK, Raney DE (1954). Two simple media for the demonstration of pyocyanin and fluorescin. The Journal of Laboratory and Clinical Medicine 44:301-307.

Kiska DL, Gilligan PH (2003). Pseudomonas. In: Manual of Clinical Microbiology. ASM Press, Washington DC, pp 719728.

Kolbert CP, Persing DH (1999). Ribosomal DNA sequencing as a tool for identification of bacterial pathogens. Current Opinion in Microbiology 2:299-305.

Koneman EW, Allen SD, Janda WM, Schreckenberger PC, Winn WC (1997). The Enterobacteriaceae. Color atlas and textbook of diagnostic microbiology. B Lippincott Co, Philadelphia, pp 71-230.

Kosanovic D, Sheehan G, Grogan H, Kavanagh K (2019). Characterisation of the interaction of Pseudomonas putida and Pseudomonas tolaasii with Trichoderma aggressivum. European Journal of Plant Pathology 1-11.

Long PE, Jacobs L (1974). Aseptic fruiting of the cultivated mushroom, Agaricus bisporus. Transactions of the British Mycological Society 63:99-107. https://doi.org/10.1016/S0007-1536(74)80140-3 
Mohammad A, Sabaa A (2015). In vitro and in vivo impact of some Pseudomonas spp. on growth and yield of cultivated mushroom (Agaricus bisporus). The Egyptian Society of Experimental Biology 11(2):163-167.

Munsch P, Alatossava T, Marttinen N, Meyer J-M, Christen R, Gardan L (2002). Pseudomonas costantinii sp. nov., another causal agent of brown blotch disease, isolated from cultivated mushroom sporophores in Finland. International Journal of Systematic and Evolutionary Microbiology 52:1973-1983. https://doi.org/10.1099/ijs.0.02090-0

Noble R, Fermor TR, Lincoln S, Dobrovin-Pennington A, Evered C, Mead A, Li R (2003). Primordia initiation of mushroom (Agaricus bisporus) strains on axenic casing materials. Mycologia 95:620-629.

O'Hara CM (2005). Manual and automated instrumentation for identification of Enterobacteriaceae and other aerobic gram-negative bacilli. Clinical Microbiology Reviews 18:147-162. https://doi.org/10.1128/CMR.18.1.147162.2005

O'Hara CM, Rhoden DL, Miller JM (1992). Re-evaluation of the API 20E identification system versus conventional biochemicals for identification of members of the family Enterobacteriaceae: a new look at an old product. Journal of Clinical Microbiology 30:123-125.

Porteous LA, Widmer F, Seidler RJ (2002). Multiple enzyme restriction fragment length polymorphism analysis for high resolution distinction of Pseudomonas (sensu stricto) 16S rRNA genes. Journal of Microbiological Methods 51:337-348.https://doi.org/10.1016/S0167-7012(02)00108-2

Scarpellini M, Franzetti L, Galli A (2004). Development of PCR assay to identify Pseudomonas fluorescens and its biotype. FEMS Microbiology Letters 236:257-260.

Topic Popovic N, Benussi Skukan A, Strunjak-Perovic I, Coz-Rakovac R, Hacmanjek M, Hunjak B (2004). Comparison of the API 20E and BBL crystal E/NF identification systems for differentiating bacterial isolates from apparently healthy reared sea bass (Dicentrarchus labrax). Veterinary Research Communications 28:93-101. https://doi.org/10.1023/B:VERC.0000012113.95479.2f
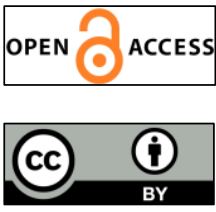

The journal offers free, immediate, and unrestricted access to peer-reviewed research and scholarly work. Users are allowed to read, download, copy, distribute, print, search, or link to the full texts of the articles, or use them for any other lawful purpose, without asking prior permission from the publisher or the author.

License - Articles published in Notulae Scientia Biologicae are Open-Access, distributed under the terms and conditions of the Creative Commons Attribution (CC BY 4.0) License.

(C) Articles by the authors; SHST, Cluj-Napoca, Romania. The journal allows the author(s) to hold the copyright/to retain publishing rights without restriction. 